Omni-Akuatika, 17 (1): 27 - 36, 2021
ISSN: 1858-3873 print / 2476-9347 online
Research Article
journal homepage: http://ojs.omniakuatika.net

\title{
Stratification And Characteristic Of Water Masses In Selayar Slope-Southern Makassar Strait
}

\author{
Isnaini Prihatiningsih ${ }^{1,2^{\star}}$, Indra Jaya ${ }^{2}$, Agus Saleh Atmadipoera ${ }^{2}$, Rina Zuraida ${ }^{3}$ \\ ${ }^{1}$ Department of Marine Science, Fishery and Marine Science Faculty, Jenderal Soedirman University, \\ Purwokerto 53122 INDONESIA
2 Department of Marine Science and Technology, Bogor Agricultural University, Bogor 16610 INDONESIA \\ ${ }^{3}$ Marine Geological Institute, Bandung Indonesia \\ "Corresponding author: isnaini.prihatiningsih@unsoed.ac.id
}

Received 8 January 2019; Accepted 2 June 2021; Available online 30 June 2021

\begin{abstract}
Selayar slope is the confluence of the Indonesian Throughflow (ITF) from the Makassar Strait and seasonal Java-Flores current. The CTD data from Java-Makassar-Flores (JMF) Cruise where an intensive 24-h CTD "yoyo" measurement was conducted in Selayar Slope is used to determine the stratification and characteristic of water masses in the Selayar slope - southern Makassar Strait. The analyses were performed using TS Diagram processed with Matlab and Ocean Data View (ODV). The surface potential density of $24.25 \sigma_{\theta}$ with stratification of water masses is dominated by Makassar ITF. The water mass with higher salinity (34.6 psu) is North Pacific Subtropical water (NPSW) and lower salinity (34.44 psu) is North Pacific Intermediate Water (NPIW). However, water mass with density above $24.25 \sigma_{\theta}$ caused NPSW to be drastically extracted by less-saline water ( $34.15 \mathrm{psu}$ ) originated from Java Sea, where salinity profiles are more clearly observed between surface density of $22.0 \sigma_{\theta}$ and $23.50 \sigma_{\theta}$.
\end{abstract}

Keyword: stratification and characteristic, water mass, Selayar Slope, JMF Cruise, TS Diagram

\section{ABSTRAK}

Selayar slope merupakan pertemuan ITF dari Selat Makassar dan Arus musiman Jawa-Flores. Data CTD dari JMF Cruise dengan pengukuran intensif CTD "yoyo" selama 24 jam yang dilakukan di Selayar slope untuk mengetahui stratifikasi dan karakteristik massa air di Selayar slope, selatan Selat Makassar. Analisis dilakukan menggunakan TS Diagram yang diolah dengan Matlab dan Ocean Data View (ODV). Densitas potensial permukaan $24.25 \sigma_{\theta}$ dengan stratifikasi massa air didominasi oleh ITF dari Selat Makassar. Massa air dengan salinitas maksimal (34.6 psu) merupakan North Pacific Subtropical water (NPSW) dan massa air dengan salinitas minimal (34.44 psu) merupakan North Pacific Intermediate Water (NPIW). Namun, massa air dengan densitas di atas $24.25 \sigma_{\theta}$ menyebabkan NPSW terekstraksi secara drastis oleh air yang lebih rendah salinitasnya (34.15 psu) yang berasal dari Laut Jawa, di mana profil salinitas terlihat lebih jelas antara densitas permukaan $22.0 \sigma_{\theta}$ and $23.50 \sigma_{\theta}$.

Kata Kunci: stratifikasi dan karakteristik, massa air, Selayar Slope, JMF Cruise, TS Diagram

\section{Introduction}

Selayar Slope is an encounter between the Java Sea, the Makassar Strait and the Flores Sea and passed by ITF. ITF is a mass of water migrating from the Pacific Ocean to the Indian Ocean through the Indonesian sea via two paths, the west and east path where the components of the water mass composed the mass of the North Pacific and South Pacific water (Wyrtki, 1961; Gordon and Fine, 1996). The west path of the ITF route is from the mass of water from the Pacific Ocean carried by the Mindanao Current penetrates into the Celebes Sea, and then flows to the Indian Ocean via the Makassar Strait, then towards the south into the Flores, Banda and Timor Seas. The second 
path is the eastern path, where a mass of water from the Pacific Ocean enters the Indonesian Sea through the Molucca Sea and the Halmahera Sea and flows to the Ceram Sea then proceed to the Banda Sea. In the Banda Sea, there was another encounter of water masses from the west and east lines before ultimately exit to the Indian Ocean through the Ombai Strait, Lombok Strait and Timor Sea (Fieux et al., 1996; Atmadipoera et al., 2009).

The Makassar Strait is the main route of the ITF that carries water masses from the North Pacific Ocean (Gordon et al., 2010; Susanto et al., 2012). The water mass from the North Pacific is composed of a mass of North Pacific Subtropical Water (NPSW) in the thermocline layer and North Pacific Intermediate Water (NPIW) in the lower layer of the thermocline. NPSW entering Indonesian waters has characteristics of high (maximum) salinity values meanwhile the NPIW has low (minimum) salinity values. In the Makassar Strait, the mass of NPSW water was found at an average depth of 300-350 dbar (Hasanudin, 1998).

ITF has high variability both seasonally and annually. Seasonal variability is influenced by the change of wind or monsoon direction in Indonesia, which is then called Armondo which is found in the surface layer at a depth of $0-50$ meters (llahude, 1997). The strongest flow of ITF water mass occurs during the southeast monsoon, June to August, while the lowest flow occurs during the northwest monsoon, December to February (Wyrtki, 1987). ITF annual variability is related to the occurrence of the ENSO (EI Nino Southern Oscillation) phenomenon, which affects the climate globally.

Selayar Slope is an intersection of ITF from the Makassar Strait, Indonesian Monsoon system originating from Java and reversing twice in one year, as well as a current intrusion from the Indian Ocean through the Lombok Strait can also penetrate into the South Makassar Strait (Wyrtki, 1961, Murray and Arief, 1998, Atmadipoera et al., 2009) The upwelling phenomenon also occurs in the Makassar Strait (Ilahude, 1970, Atmadipoera and Widyastuti, 2015) and in the southern waters of South Sulawesi (Main, 2017). Water mass stratification plays an important role in many bio-geo-chemichal processes (Hermansyah et al. 2017). Mixed layer arrange interaction deep layer and upper layer. From the phenomena that occur in this region it is considered that the Selayar Slope has distinctive and interesting characteristics to be studied and understood. This research was aimed to determind stratifikasi and characteristics of Selayar Slope.

\section{Materials and Methods}

\subsection{Data Sampling}

Field data collection was conducted on August $13^{\text {th }} 2015$ from JMF cruise using the Geomarin III Research vessel from Marine Geological Institute (P3GL), Balitbang ESDM Bandung. JMF Cruise is part of the joint research between the Faculty of Fisheries and Marine Sciences (FPIK) IPB and P3GL. Cruising activities were performed around the waters of the Java Sea, Makassar Sea and Flores Sea. The study located at $6.8138^{\circ} \mathrm{S}$ and $119.4456{ }^{\circ} \mathrm{E}$ (Figure 1). Tidal data is obtained from Online Tidal Prediction, Geospatial Information Agency (Badan Informasi Geospasial: BIG) (http://tides.big.go.id/). The tidal data used is the hourly time series data on August 13, 2015 from 00.00 to 23.59 hours which is adjusted to the CTD data recording period. Data was analyzed in the Physical Oceanography Laboratory of the Marine Science and Technology FPIK IPB.

Data derived and used for this study are data on temperature, salinity, pressure, and density. Data are obtained using the Conductivity Temperature Depth (CTD) SeaBird Electronic (SBE) 19 Plus Conductivity Temperature instrument. The CTD data used is data at station 22 on the JMF cruise. CTD "yoyo" was cast by 11 times in 24 hours (one tidal cycle) with different depths which began at 01.11 to 23.50 local time, but on the $7^{\text {th }}$ test a technical error occurred resulting in only 10 replications. The sampling rate used on the SBE 19 Plus CTD instrument is $4 \mathrm{~Hz}$ (recording four data in one second). Information on position, time, and depth of CTD casts is shown in Table 1. CTD recording data is raw data that must be downloaded first and requires further data processing. 
Table 1. Information on position, time, and depth of cast of CTD on Selayar Slope

\begin{tabular}{|c|c|c|c|c|c|}
\hline \multirow[b]{2}{*}{$\begin{array}{c}\text { Sampling } \\
\text { No }\end{array}$} & \multicolumn{2}{|c|}{ Position } & \multirow[b]{2}{*}{ Date } & \multirow[b]{2}{*}{ Time } & \multirow[b]{2}{*}{$\begin{array}{l}\text { Depth o } \\
\text { CTD (m) }\end{array}$} \\
\hline & $\begin{array}{c}\text { Lon } \\
\text { (degree) }\end{array}$ & $\begin{array}{c}\text { Lat } \\
\text { (degree) }\end{array}$ & & & \\
\hline 22_01 & 119.4453 & -6.8138 & $13 / 8 / 2015$ & 01.11 & 631 \\
\hline 22_02 & 119.4453 & -6.8138 & $13 / 8 / 2015$ & 03.35 & 593 \\
\hline 22_03 & 119.4453 & -6.8138 & $13 / 8 / 2015$ & 06.10 & 739 \\
\hline 22_04 & 119.4453 & -6.8138 & 13/8/2015 & 08.30 & 777 \\
\hline 2205 & 119.4453 & -6.8138 & $13 / 8 / 2015$ & 10.45 & 708 \\
\hline 22_06 & 119.4453 & -6.8138 & $13 / 8 / 2015$ & 13.13 & 556 \\
\hline 22_07 & - & - & - & - & - \\
\hline 22_08 & 119.4453 & -6.8138 & $13 / 8 / 2015$ & 17.30 & 478 \\
\hline 2209 & 119.4453 & -6.8138 & $13 / 8 / 2015$ & 19.30 & 539 \\
\hline $22 \_10$ & 119.4453 & -6.8138 & $13 / 8 / 2015$ & 21.40 & 527 \\
\hline $22 \_11$ & 119.4453 & -6.8138 & $13 / 8 / 2015$ & 23.50 & 591 \\
\hline
\end{tabular}

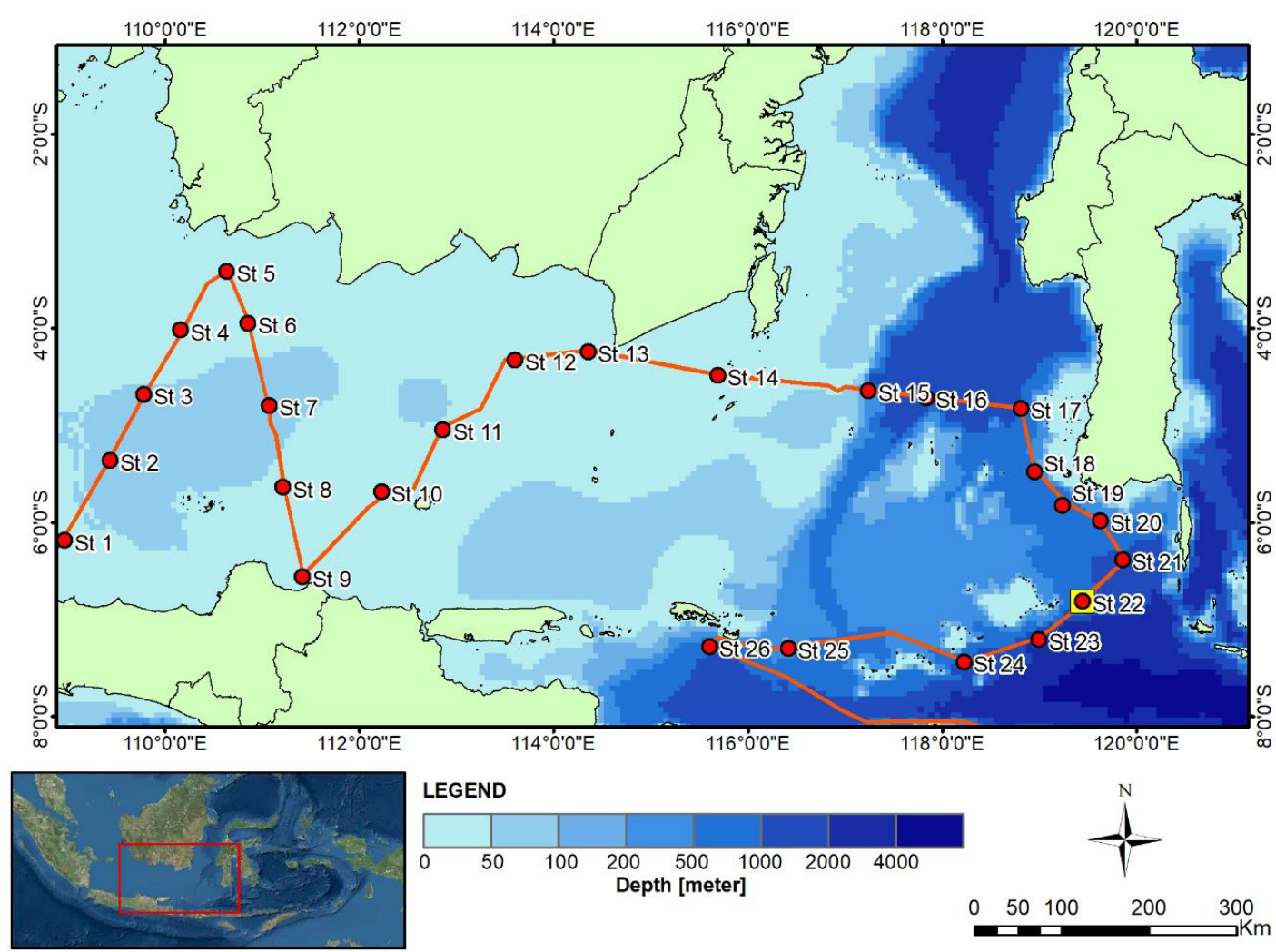

Figure 1. Map study area in JMF Cruise 2015, red dot is site points of CTD cast. The yellow square denotes for 24-hour repeated "yoyo" CTD measurement on 13 August 2015 in Selayar Slope.

\subsection{Data Analysis}

\subsubsection{Pre Processing CTD Data}

The instrument was configured which included the determination of frequency rate, recording time and adjustments to the general conditions of the location of instrument deployment before the instrument was cast. At station 22 CTD is configured with a frequency rate of $4 \mathrm{~Hz}$ and a $1 \mathrm{~ms}^{-1}$ decrease in tool speed. CTD Data Processing is done by converting raw data before being analyzed using SBE Data Processing software 7.21. The stages of CTD data pre-processing using SBE Data Processing software (Seabird Electronics, 2006) include: Data Conversion, Align CTD, Cell thermal mass, Loopedit, Filter, Bin Average.

The next step is to re-correct data that has been pre-processed. This step aims to eliminate noise that is still present in the data. The converted data in the * ${ }^{*}$.cnv format that has been corrected or filtered is analyzed using Ocean Data View 4, Microsoft Excel 2010, and Matlab software. 


\subsubsection{Processing CTD Data}

CTD data that has gone through the preprocessing and corrected stages are then processed using Ocean Data View (ODV) and Matlab software. Processing using ODV 4 produces a transverse distribution of temperature, salinity, and density. Vertical distribution profiles and TS diagrams are processed using Matlab. The process of compiling data is carried out following the format required for ODV 4 and Matlab.

\subsubsection{Determination of Water Mass Layer}

The water column layer is divided into three; the mixed layer (homogeneous), the thermocline layer, and the deep layer. Determination of this water layer is based on temperature gradient and water column density or threshold gradient method. Characterization of the mass layer of water into a mixed surface layer (surface mixed layer) is conducted by observing the temperature gradient $(\Delta T)<0.1$ ${ }^{\circ} \mathrm{C}$. The thermocline layer has a temperature gradient of $\geq 0.1{ }^{\circ} \mathrm{C}$ and a density gradient of $\geq 0.02 \mathrm{~kg} \cdot \mathrm{m}^{-3}$ with reference surface density points (Thomson and Fine, 2003; Cisewski et al., 2005). The boundary between the thermocline layer and the homogeneous deep layer is seen visually from the density data cross-checked with temperature data, the boundary is determined by the depth range where the density value does not sharply decrease with depth.

\subsubsection{Water Mass Characteristic}

Analysis of the physical characteristics of water masses is performed by illustrating the potential temperature-salinity diagram (TS diagram) using Matlab software. The TS diagram illustrates the relationship between temperature and salinity observed simultaneously at various depths of the water column. TS Diagram serves as an identifier of the character and source of a body of water as well as a method that can be used in the study of mixing masses of water (Thomson and Emery, 2014). This analysis is very useful and able to provide the best explanation for analyzing types of water, such as water mass with a certain temperature and salinity value; and water masses (Neumann and Pierson, 1966). Specifically, this analysis is intended to identify the origin of the reference of water mass as referred by classification by Wyrtki (1961).

\section{Results and Discussion}

\subsection{Vertical Profile of Temperature, Salinity, and Density}

The stratification pattern of water masses in ITF path can be seen through the vertical profile of temperature, sanity, and density (Figure 2). The vertical profile of the temperature shows the maximum value in the surface layer and fluctuations in the thermocline layer, then it decreases drastically and is relatively homogeneous in the deep layer. The vertical profile of temperature in Selayar slope can be divided into 3 layers; the mixed layer (homogeneous layer), the thermocline layer, and the deep layer. Determination of water column layer is based on a temperature gradient $(\Delta T)$ and density $\left(\Delta \sigma_{\theta}\right)$ (Thomson and Fine, 2003). If $\Delta T<0.1^{\circ} \mathrm{C}$ and $\Delta \sigma_{\theta}<0.02 \mathrm{~kg} . \mathrm{m}^{-}$ ${ }^{3}$, it is categorized as a mixed layer. The mixed layer has a relatively homogeneous temperature and is highest due to mixing caused by wind friction. It is categorized as a thermocline layer if the value is $\Delta T \geq 0.1^{\circ} \mathrm{C}$ and $\Delta \sigma_{\theta} \geq 0.02 \mathrm{~kg} \cdot \mathrm{m}^{-3}$. The thermocline layer is a boundary layer between the mixed surface layer and the deep layer, where a drastic decrease in temperature to depth is found in this layer. Finally, it is categorized as a deep layer if the values of density and temperature do not decrease sharply against the depth (Cisewki et al., 2005). The deep layer is a layer with relatively homogeneous temperature characteristics and decreases in temperature very slowly.

The highest temperature value and almost uniform characteristics are found in mixed layers (homogeneous layer). This layer has a relatively homogeneous temperature value due to mixing caused by wind friction (Steward, 2003). The surface layer mixed in Selayar slope has an average temperature of $26.42{ }^{\circ} \mathrm{C}$ and reaches a depth of up to $42 \mathrm{~m}$ with an average temperature change of $0.0059^{\circ} \mathrm{C}$. The average values of temperature in the mixed layers in all sampling numbers ranged from $26.30-26.46^{\circ} \mathrm{C}$, while the average values of density and salinity ranged from $22.28-22.34 \mathrm{~kg} \cdot \mathrm{m}^{-3}$ and $34.18-$ 34.22 psu. Setiawan et al. (2010) stated that sea surface temperatures in South Sulawesi ranged from $29-30{ }^{\circ} \mathrm{C}$ in May while in June, sea surface temperatures were low and had a drop in peak $\left(\sim 3{ }^{\circ} \mathrm{C}\right)$ in August. Sea surface temperature in August on the southern side of southern Sulawesi has decreased to reach $26.70^{\circ} \mathrm{C}$, where the temperature decline begins 
in May-September (Main, 2017). One factor that causes a decrease in sea surface temperature is the occurrence of upwelling in the Makassar Strait (Atmadipoera \& Widyastuti, 2014). llahude (1970) also found upwelling in the Makassar Strait with the distribution of low sea surface temperatures ranging from $26.40{ }^{\circ} \mathrm{C}$ $27.80{ }^{\circ} \mathrm{C}$ in August-September meanwhile in other months sea surface temperatures in the Makassar Strait ranging from $28.00{ }^{\circ} \mathrm{C}-29.20$ ${ }^{\circ} \mathrm{C}$. The first sampling has the thinnest mixed layer of $26 \mathrm{~m}$, and on contrary, the $9^{\text {th }}$ and $10^{\text {th }}$ sampling discovered the thickest homogeneous layers, reaching $51 \mathrm{~m}$. The difference in thickness of the mixed layer can result from differences in the friction strength of the wind that occurs in these waters.

Under the mixed layer there is a thermocline layer where the temperature value will decrease dramatically to depth. The average decreasing value of temperature in this layer was studied at $0.68{ }^{\circ} \mathrm{C}$. The thickness of this layer ranges from $43-315 \mathrm{~m}$. Umasangaji (2006) stated that in the eastern season period (August 1993) the upper limit of the thermocline reached $54.63 \mathrm{~m}$ in the Makassar Strait. The thermocline layer is also found at depths of 60$300 \mathrm{~m}$ (Ilahude and Gordon, 1996). This range is not much different from the results found in this study. From the results of CTD measurements, the average temperature range of the mixing layers was found between 14.16-
$26.15{ }^{\circ} \mathrm{C}$ with an average of $16.01{ }^{\circ} \mathrm{C}$. The salinity and density values increase with increasing depth. In the mixed layer, the salinity and density range from 30.65-34.63 psu and $22.36-25.74 \mathrm{~kg} \cdot \mathrm{m}^{-3}$ with an average value of $34.48 \mathrm{PSU}$ and $25.26 \mathrm{~kg} \cdot \mathrm{m}^{-3}$.

The lowest layer is the deep layer at a depth greater than $315 \mathrm{~m}$. The deep layer has the lowest and almost homogeneous temperature value. In this layer, there is a decrease in temperature but the decrease is not as sharp as in the thermocline layer. The temperature value in the layer is between 6.83$10.13^{\circ} \mathrm{C}$ with a change in average of $0.01{ }^{\circ} \mathrm{C}$. The salinity and density values in this layer have the highest value, but not much changes and are almost homogeneous. Salinity and density values range from $34.44-34.51$ psu and $26.50-27.06 \mathrm{~kg} \cdot \mathrm{m}^{-3}$.

\subsection{Distribution of temperature and salinity over one tidal period}

The distribution of temperature (Figure 3) and salinity (Figure 4) over one tidal period has water mass stratification characteristics based on depth. The value of temperature decreases with increasing depth, and salinity will increase in the thermocline layer. The combination of temperature and salinity stratification patterns is indicated by density stratification.
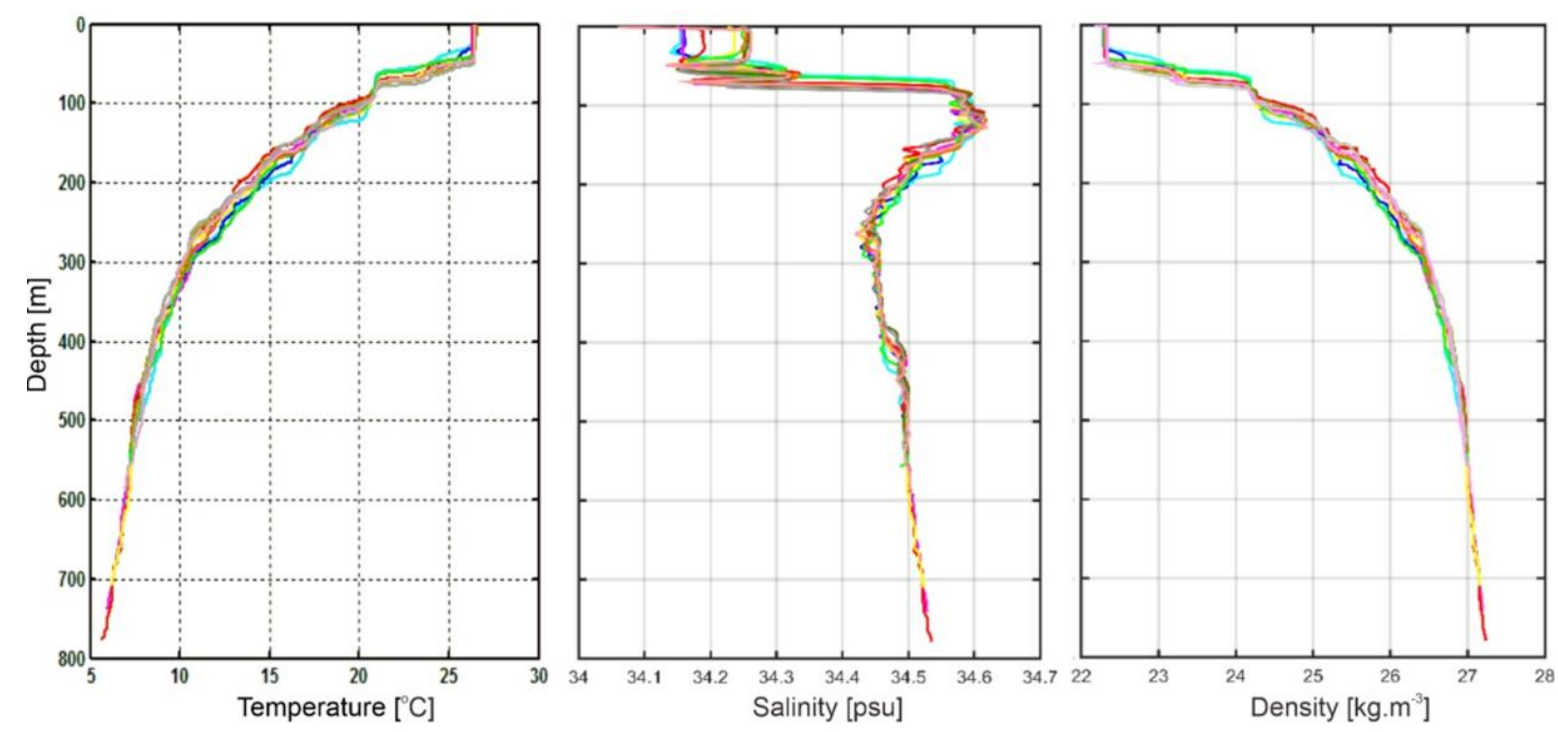

Figure 2. Vertical profile of temperature, salinity, and density from 10 CTD cast measurement in Selayar Slope 


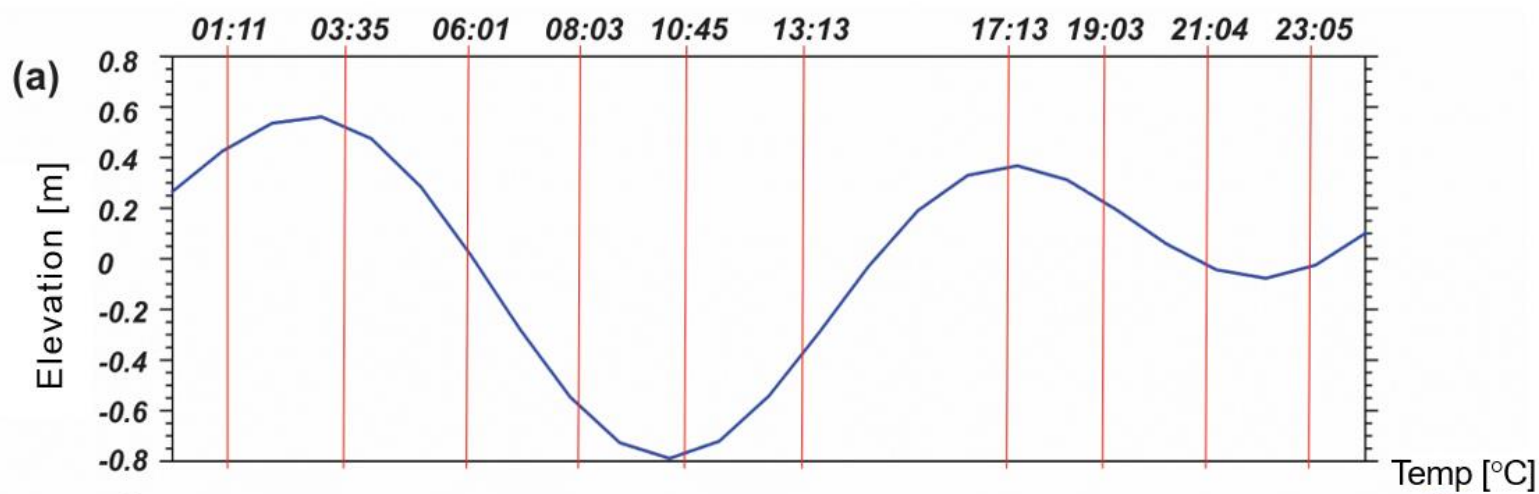

(b)

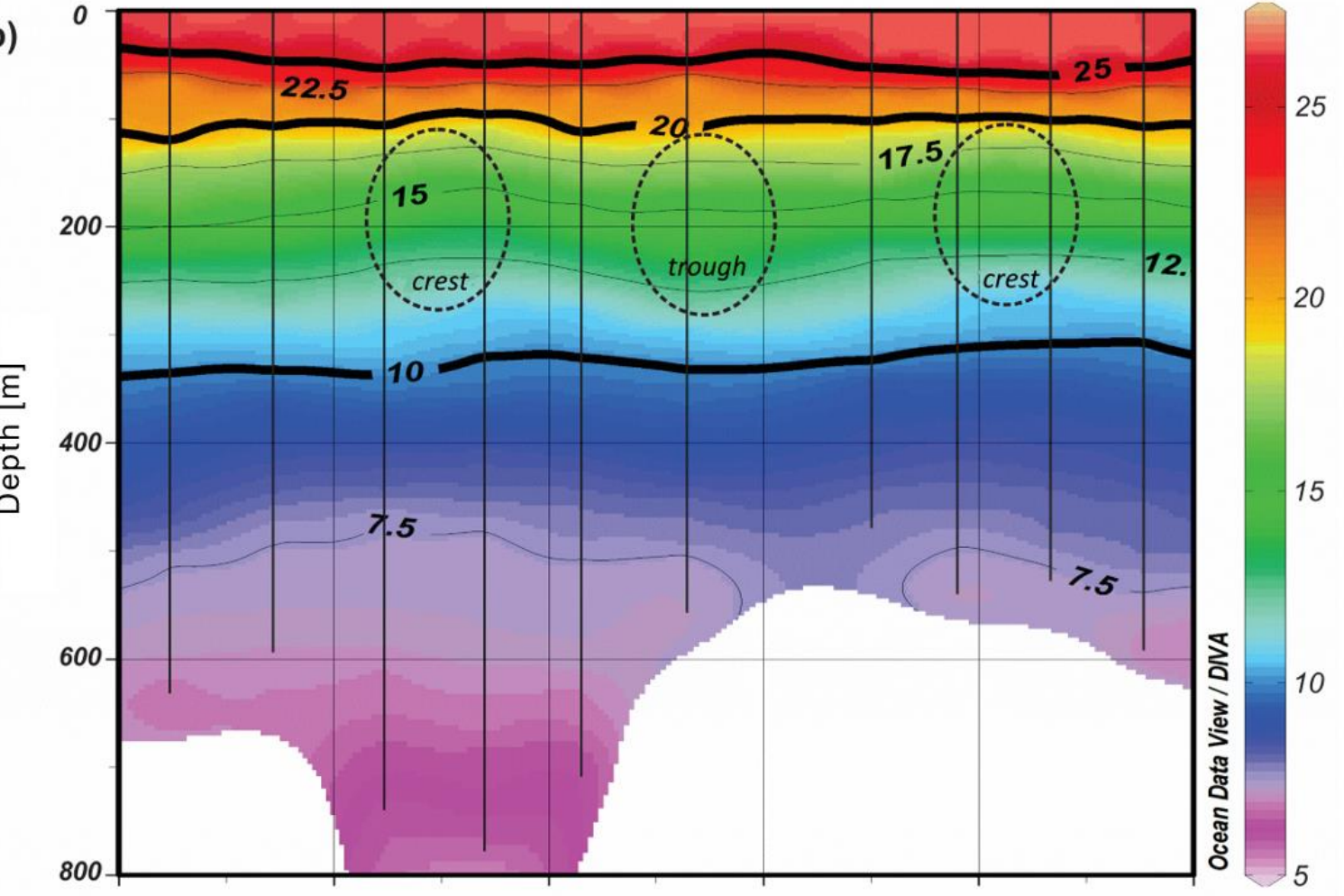

Figure 3. Tidal prediction on August 13, 2015 (a) and distribution of temperature from 10 CTD cast measurement over one tidal period (b) in Selayar Slope

The results of the temperature distribution show the insignificant difference in temperature values during one tidal period, only a slight difference in isothermal thickness was found that can be caused due to tidal influences. The thickness of the mixed layer reaches a depth of $42 \mathrm{~m}$ with the thinnest mixed layer analyzed at the first sampling with a depth of $26 \mathrm{~m}$ occurring around the highest tide, meanwhile the thickest mixed layer in the $9^{\text {th }}$ and $10^{\text {th }}$ sampling occurring around the low tide. In the thermocline layer $(43-315 \mathrm{~m})$ there is a drastic decrease in temperature illustrated by isothermal lines (20-10) that form crest and trough on 17.5, 15, and 12.5 isothermal line (Figure 3). The deep layer experiences a temperature change but not as sharp as in the thermocline layer. 

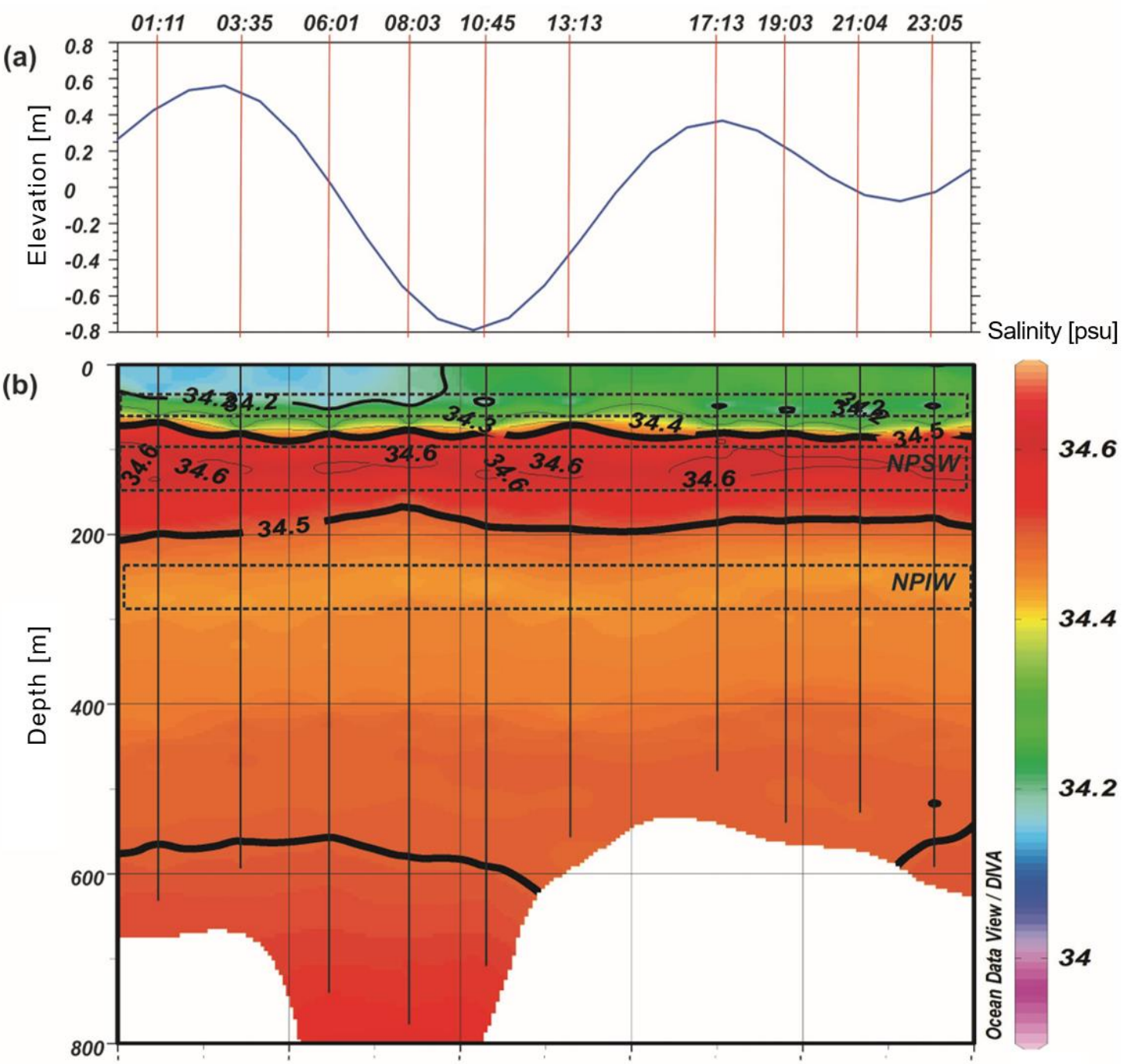

Figure 4. Tidal prediction on August 13, 2015 (a) and distribution of salinity from 10 CTD cast measurement over one tidal period (b) in Selayar Slope

Distribution of salinity (Figure 4) retrieved from CTD data in the mixed layer shows water mass with low salinity $(34.2-34.3 \mathrm{psu})$ from $1^{\text {st }}$ to $11^{\text {th }}$ sampling. Salinity values increase with the increasing depth. The salinity value has decreased at a depth of $60 \mathrm{~m}$. This happens because the heat spreads so that an unstable thin layer appears between the two stable layers. This process is called salt fingering, which is the presence of a mass of warm and salty water above a mass of cold and less salty water (Steward 2002). The upper thermocline layer shows high salinity (red). This high-salinity water mass is assumed to be a mass of North
Pacific Subtropical Water (NPSW) water carried along by ITF through the Makassar Strait. According to Gordon and Fine (1996) NPSW water masses are characterized by water masses that have maximum salinity values in the upper thermocline layer. Water mass with low salinity in the intermediate layer or lower layer of thermocline that characterizes the mass of North Pacific Intermediate Water (NPIW) is also detected at a depth of about 250-350 m. The deep layer possesses a salinity value ranged from $34.5 \mathrm{psu}$ and is almost homogenous to the bottom of the water. 


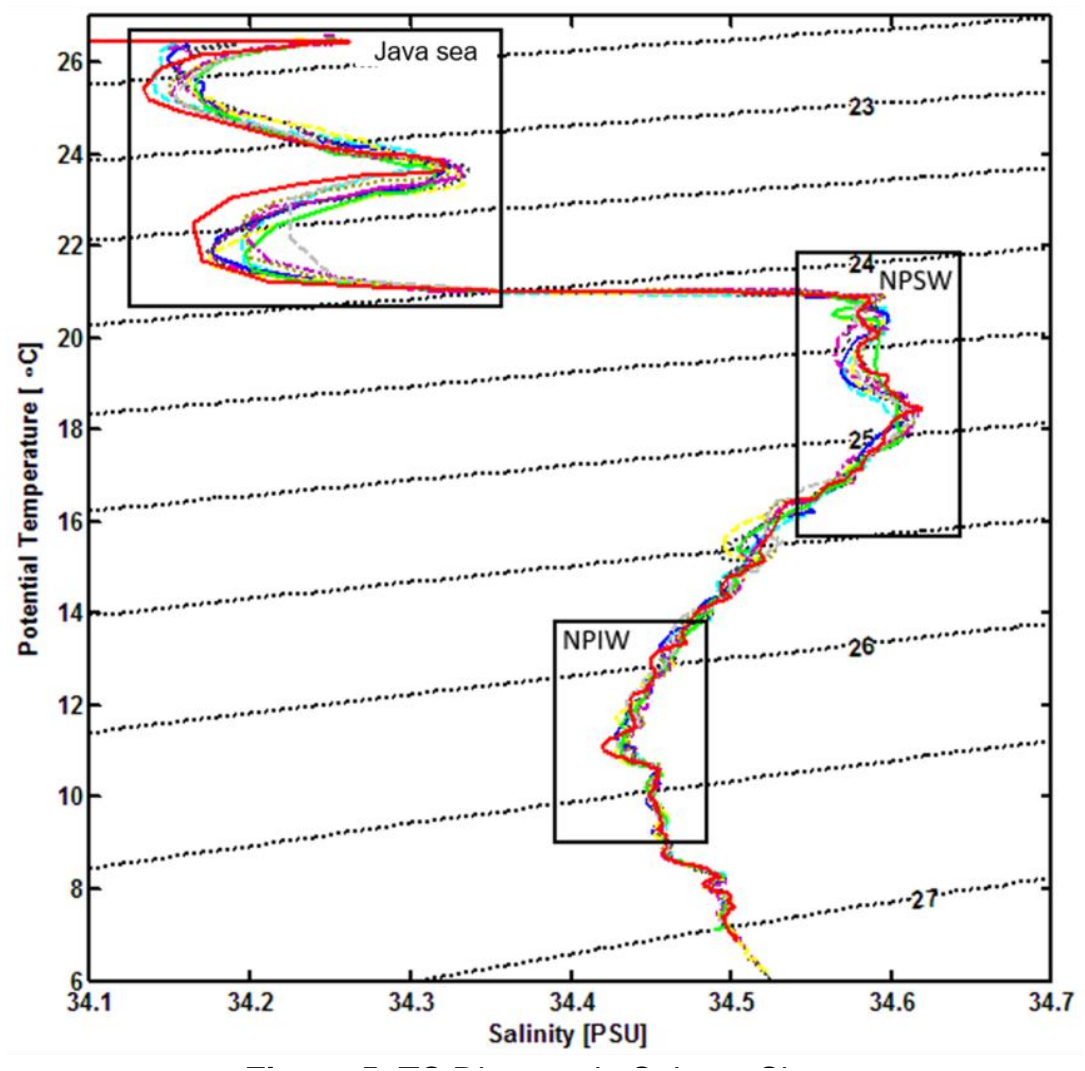

\subsection{Characteristics of Selayar Water Mass}

The characteristics of the water mass that passes through the Selayar Slope can be understood through the TS diagram as illustrated in Figure 5 . The results of the identification of water mass character types are presented in Table 2. The water mass in the Selayar Slope generally has low salinity (34.13$34.16 \mathrm{psu})$ at $\sigma_{\theta}=22.3-22.7 \mathrm{~kg} \cdot \mathrm{m}^{-3}$ and (34.16-34.22 psu) at $\sigma_{\theta}=23.5-23.7 \mathrm{~kg} \cdot \mathrm{m}^{-3}$ in the mixed layer at depths of $40-46 \mathrm{~m}$ and $59-62$ $\mathrm{m}$. This water mass is assumed to be the water mass that originated from the Java Sea which move eastward. This result is similar to the results obtained by Atmadipoera et al., (2009) through a data study using the KL07 model which shows surface layers to the thermocline layer experienced salinity dilution in several locations due to excessive rainfall in the Java Sea which moves eastward. The salinity increases at $\sigma_{\theta}=22.3-22.7 \mathrm{kgm}^{-3}$, this is related to the stability of the water mass, especially the double-diffusion type which is related to changes in temperature and salinity in the oceans. The thin water layer is separated by a sharp gradient, the top layer is warm and salty and the bottom layer is colder and less salty, so this layer will be less stable. This process is called salt fingering (Steward 2002). Atmadipoera and Widyastuti (2014) stated that the mass of water on the surface has a weaker current speed causing currents to experience recirculation due to the presence of Selayar Island and following the direction of the ITF path which has greater speed. Water mass with low salinity which is assumed to be originated from the Java Sea in the west monsoon is still detected in the east monsoon in this area.

The second water mass showed in $\sigma_{\theta}=24.2-25.1 \mathrm{~kg} \cdot \mathrm{m}^{-3}$ has higher salinity value compared to the first water mass found on the surface. The maximum salinity values ranged from 34.58-34.59 psu which are found in the $81-143 \mathrm{~m}$ depth range. The value of the second water mass temperature ranged from $17.26-20.84{ }^{\circ} \mathrm{C}$. This water mass is assumed to be mass of North Pacific Subtropical Water (NPSW) water. NPSW is part of the global water mass that flows through ITF to the Indian Ocean through Indonesian waters. The maximum salinity value in the top layer of the thermocline has decreased throughout the ITF flow. Based on the research results of Naulita (2016) in the Labani Canal, the maximum salinity values were found from 34.9 psu to 34.6 psu. Risko et al. (2017) stated that in Dewakang waters the maximum salinity of NPSW ranged from $34.43-34.49 \mathrm{psu}$. This decrease in salinity indicates a mixing process along the ITF flow to the Selayar slope. 
Table 2. Characteristics of Selayar Slope Water Mass

\begin{tabular}{lllll}
\hline $\begin{array}{l}\text { Water } \\
\text { Type }\end{array}$ & Mass & \multicolumn{2}{l}{ Characteristics of Water Mass } & \\
Depth $(\mathrm{m})$ & Potential Temperature $\left({ }^{\circ} \mathrm{C}\right)$ & Salinity $(\mathrm{psu})$ & Density $\left(\mathrm{kg} \cdot \mathrm{m}^{-3}\right)$ \\
\hline Java Sea & $40-46$ & $24.9-26.25$ & $34.13-34.16$ & $22.3-22.7$ \\
& $59-62$ & $21.4-22.1$ & $34.16-34.22$ & $23.5-23.7$ \\
NPSW & $81-143$ & $17.26-20.84$ & $34.58-34.59$ & $24.2-25.1$ \\
NPIW & $251-316$ & $10.1-12.6$ & $34.43-34.45$ & $26-26.5$ \\
\hline
\end{tabular}

The lower thermocline layer shows a water mass with a minimum salinity (34.43-34.45 psu) which is hypothesized to be the mass of North Pacific Intermediate Water (NPIW) at $\sigma_{\theta}=26-$ $26.5 \mathrm{~kg}^{-3} \mathrm{~m}^{-3}$. This third water mass has temperature value of $10.1-12.6{ }^{\circ} \mathrm{C}$. Similar results were obtained by Atmadipoera et al. (2009) where the mass of NPSW and NPIW water is characterized by $\sigma_{\theta}$ of 2.5 and 26.5 $\left(\mathrm{kg} \cdot \mathrm{m}^{-3}\right)$ respectively. In the exit channel of ITF, NPSW and NPIW water mass are characterized by possessing salinity values around 34.53 and 34.47 psu. Upon entering ITF, the NPSW water mass experiences increasing salinity of 34.9 psu (Atmadipoera et al., 2009), while the results of observations in the Makassar Strait and Flores Sea show that NPIW has low salinity of 34.4 psu (Ilahude and Gordon, 1996).

\section{Conclusion}

The water mass in Selayar slope composed by the water mass of Java Sea, water mass of North Pacific Subtropical Water (NPSW) and water mass of North Pacific Intermediate Water (NPIW). NPSW below the surface layer characterized by temperature value of $17.26-20.84{ }^{\circ} \mathrm{C}$ and maximum salinity of 34.58-34.59 psu at a depth of 81-143 m, and NPIW in the lower thermocline layer at a depth of 251-316 $\mathrm{m}$ is characterized by temperature of 10.1-12.6 ${ }^{\circ} \mathrm{C}$ and salinity 34.43-34.45 psu. Water mass originated from the Java Sea found in surface layer is characterized by temperature of $24.9-26.25^{\circ} \mathrm{C}$ and salinity of $34.13-34.16$ psu at a depth of $40-46 \mathrm{~m}$ and Kangean waters is characterized by having a temperature of 21.4$22.1{ }^{\circ} \mathrm{C}$ and salinity value $34.16-34.22$ psu found at a depth of $59-62 \mathrm{~m}$.

\section{References}

Atmadipoera A.S., Molcard R., Madec G., Wijfels S., Koch-Larrouy A., Jaya I., Supangat A., Sprintall J. 2009. Characteristics and variability of the Indonesian throughflow water at the outflow straits. J. Deep-Sea Res. I. 56(11): 1942-1954.
Atmadipoera A.S. and Widyastuti P. 2014. A numerical modeling study on upwelling mechanism in Southern Makassar strait. J. Ilmu dan Teknologi Kelautan Tropis. 6(2): 355-371.

Cisewski B., Strass V.H., Prandke H. 2005. Upper-ocean vertical mixing in the Antarctic polar front zone. J Deep-Sea Res. I/ 52:1087-1108.

Fieux, M., Andrie C., Charriaud E., Ilahude A.G., Metzl N., Molcard R., Swallow J.C. 1996. Hydrological and chlorofluoromethane measurements of the Indonesian throughflow entering the Indian Ocean. J. of. Geophys. Res. 101(C5): 12433-12454.

Gordon A.L. and Fine R.A. 1996. Pathways of water between the Pacific and Indian Ocean in the Indonesian Sea. Nature. 379: $146-149$

Gordon, A., Sprintall J., Van Aken H.M., Susanto D., Molcard R., Ffield A., Pranowo W., Wirasantosa S., Wijffels S. 2010. The Indonesian throughflow during 2004-2006 as observed by the INSTANT program. J. Dyn. of Atmos. and Oceans. 50(2):115-128.

Hasanudin M. 1998. Arus lintas Indonesia (ARLINDO). Oseana. XXIII (2): 1-9.

Hermansyah H, Atmadipoera A.S., Prartono T., Jaya I., Syamsudin F. 2017. Stratification and Stability of Seawater Mass in Sulawesi Sea. International Journal of Sciences: Basic and Applied Research. 36(8): 36-44.

llahude A.G. 1970. On the occurrence of upwelling in the Southern Makassar Strait. Lembaga Penelitian Laut.

llahude A.G., Gordon A.L. 1996. Thermocline stratification within the Indonesian Seas. J. Geophys. Res. 101: 12401-12409.

Lorbacher K., Dommenget, Niiler P.P., Kohl A. 2005. Ocean Mixed Layer Depth: a Subsurface Proxy of Ocean-Atmosphere Variability. San Diago: The ECCO Report Series. 
Murray S.P., Arief D. 1988. Throughflow into the Indian Ocean through the Lombok Strait, January 1985-January 1986. Nature. 333: 444-447.

Naulita Y. 2016. Proses percampuran turbulen di kanal Labani, Selat Makassar. J. IImu dan Teknologi Kelautan Tropis. 8(1): 345-355.

Risko, Atmadipoera A.S., Jaya I., Sudjono E.H. 2017. Analysis of turbulent mixing in Dewakang Sill, Southern Makassar Strait. IOP Conf. Ser.: Earth Environ Sci.

SeaBird Electronics. 2005. Seasoft V2: SBE Data Processing. Believue, Washington (USA): Sea-Bird Electronics. Inc.

Steward R.H. 2002. Introduction to Physical Oceanography. Texas A\&M University: Departement of Oceanography.

Susanto R.D., Ffield A., Gordon A.L., Adi T.R. 2012. Variability of Indonesian throughflow within Makassar Strait, 2004-2009. J. of Geophys Res. 117(C09013): 1-16. doi: 10.1029/2012JC008096

Thomson R.E., I.V. Fine. 2003. Estimating mixed layer depth from oceanic profile data. J. Atmos. and Oceanic Technol. 20: 319-329.

Thomson R.E., Emery W.J. 2014. Data Analysis Methods in Physical Oceanography. Oxford (US) Newnes. $728 \mathrm{p}$.

Umasangaji H. 2006. Variabilitas dan karakteristik arus lintas Indonesia hubungannya dengan fluktuasi lapisan termoklin di Perairan Selat Makassar [tesis]. Bogor (ID): Instritut Pertanian Bogor.

Utama F.G. 2017. Analysis of upwelling event in Southern Makassar Strait. IOP Conf. Series: Earth and Environmental Science. doi: 10.1088/17551315/54/1/012085.

Wyrtki K. 1961. Scientific Results of Marine Investigations of the South China Sea and the Gulf of Thailand 1959-1961. Naga Report Volume 2.

Wyrtki K. 1987. Indonesian Through Flow and the Associated Pressure Gradient. J. of Geophys. Res. 92:12941-12946. 